\title{
LOOKS LIKE VISCERA
}

\section{Folds, Wraps, and Relations in the Southern Andes}

Francisco Pazzarelli

\begin{abstract}
This article explores how viscera, bodies, and forces emerge in resemblance to one another. In the connections between the animals' butcher, the treatment of body parts, and the rituals of herd marking in the Argentinean highlands, folds and wrappings of viscera, leathers, meats, and dances make things 'look like' something else in different scales, highlighting correspondences or reflections between entities. Each level of these compositions refers to another, and a change in one can affect all of them. Resemblances are constantly evaluated and topologically manipulated, either to enable their mutual stimulation or to avoid connections and thus to establish differences between the perspectives of different beings. This article argues that the fabrication of similarities and differences through the manipulation of resemblances offers a privileged key to an understanding of Andean and Amerindian sociality.
\end{abstract}

Keywords: Argentina, body, perspectivism, relations, resemblances, Southern Andes, topology, viscera

La société, nous le savons maintenant, consiste dans un échange de reflets.

- Gabriel Tarde, Fragment d'histoire future

Among the Andean shepherds of Huachichocana in northern Argentina, the loops and spiraling shape of the upper colon of sheep and goats are food for thought. The central flexure of the colonic disc defines a transitional segment in the gut, where the centripetal force moving the fecal matter inward becomes centrifugal and drives it toward the rectum, where it is expelled out of the body (fig. 1). The people of Huachichocana call this gut a corral, using the same Spanish word they use for animal corrals. According to them, there are strong resemblances, or señas, between the stone pens where goats and sheep are kept and 


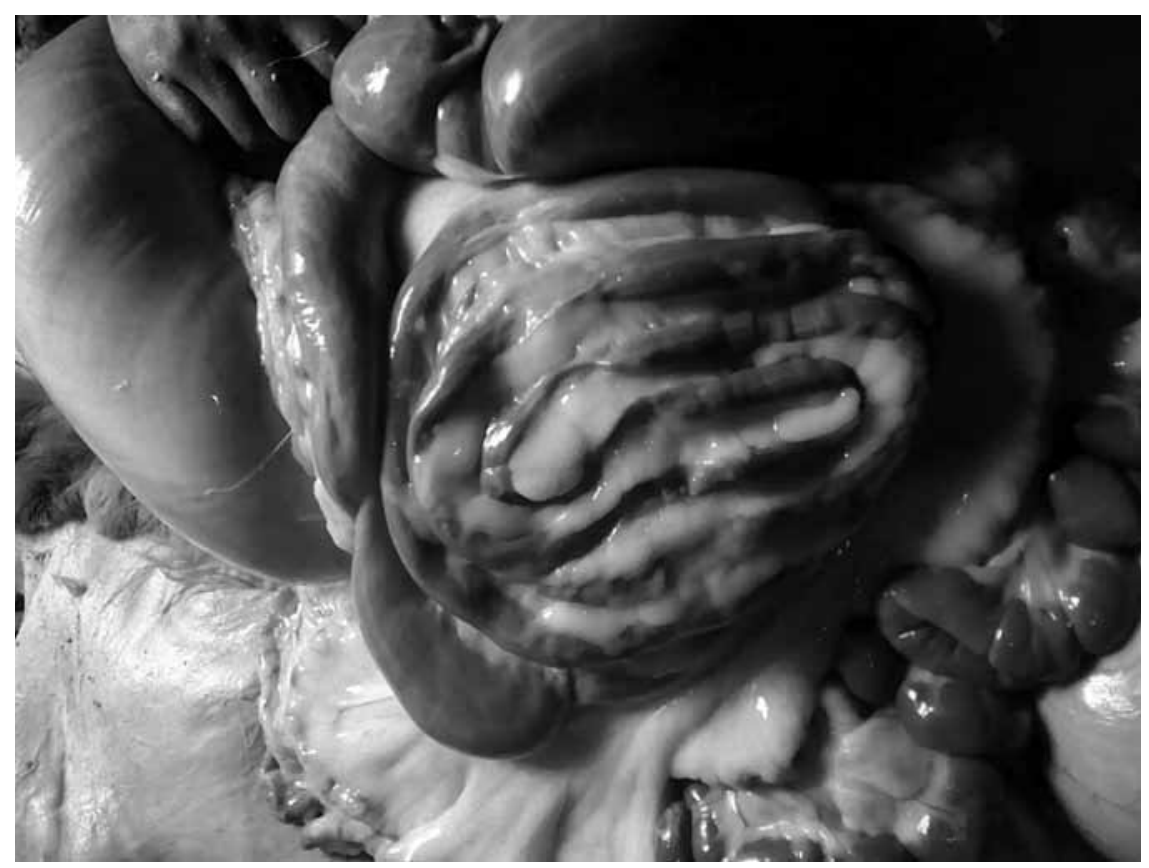

Figure 1: Corral of guts. Huachichocana, August 2018. Photograph ${ }^{\circledR}$ Francisco Pazzarelli

the loops of the guts that the animals have wrapped in their bodies. "It is a corral because it looks like a corral," they argue. This article serves as a departure point to explore the nature of forms and forces in the Southern Andes.

English anthropologist Tristan Platt (1986: 255-256; cf. Harris 1986) suggested that contemporary (and probably past) Andean thought privileges square shapes and especially corners to deal with different levels of sociocosmological dualism and oppositions, approaching a 'logic of forms' (LéviStrauss 1966). These relations between forms seem to be everywhere, reflecting each other as mirrors. This "reflection" is described as a "redundant repetition" or "homology" between different levels of thought and social organization, one containing another (Platt 1986: 235, 255). Along with Platt's ideas, Bastien ([1978] 1996: 93) wrote that humans and mountains (and other beings) are related as "infinite reflections of mirrors of different shapes," like a fractal multiplication (see also Bastien 1985: 609n2). In this article I will return to this pertinent (and beautiful) insight of 'thinking with forms' to explore the ethnographic material of Huachichocana, a small indigenous community of the Argentinian Andes. However, as suggested by the initial example, rather than lines and squares, I will focus on circular and spiral ${ }^{1}$ forms and forces, and on the topological operations of folds and wrappings. 
To do so, I will discuss part of my ethnographic work carried out over the last few years, describing the ways in which these relations emerge during the process of animal butchering and in the señaladas, the rituals of herd marking. First, I will present some insights on the relational universe associated with corrals that reveal the importance of folding and wrapping operations as conditions for existence. In dialogue with other authors (Arnold and Yapita 2001; Cereceda (1976) 2010; Franquemont et al. 1992), I will discuss how these forms, folds, and wraps could be seen as forces that are replicated in different scales. The resemblances between forms/forces help to reveal connections between different beings and domains of local socio-cosmology. Similar ideas have been described as an expression of an Andean animism (Allen 1982, 2015) and as part of a thought that would develop, at least partially, from different 'correspondences' or 'analogies' (Arnold 1996; Arnold and Yapita 2001; Arnold et al. 1992; Arnold et al. 1996). Second, I will discuss how these resemblances may connect unwanted worlds of relations, especially those enacted from the perspective of predators, such as pumas, that try to attack the shepherd's world of relations. I will argue that folds and wrappings can be manipulated in order to twist these relations and to prevent connections. At this point, it is important to consider the Andean reflections on merographic connections (Arnold and Yapita 2001; Strathern 1999) and on perspectivism (Allen 2015; Arnold and Yapita 2006; Viveiros de Castro 2002) that would allow us to evaluate and describe different types of resemblances. Finally, I will advance some ideas to illustrate that the ways of establishing relations in the mountains are a constant game involving the construction of similarities and differences. In keeping with the comparative spirit of this special issue, I will also reflect upon the potential Andean contribution toward a more general discussion about relations in the Amerindian world.

\section{Topologies of Butchering}

Huachichocana is a small aboriginal community located in the ravine and prePuna region of the Tumbaya department (Jujuy, Argentina), at 3,200-4,000 meters altitude. During my fieldwork, seven families permanently inhabited the place, comprising about 30 to 40 people, including adults and children. This number increases during some rituals or feasts, with the arrival of relatives who have migrated to nearby communities and towns. The huacheños have a pastoral agricultural economy, based on the cultivation of different kinds of potatoes, fava beans, maize, and alfalfa (grown to feed livestock) and on the breeding of sheep and goats (the main source of meat, milk, leather, and wool), along with some llamas, cows, pigs, and chickens. Despite this productive diversity, they recognize themselves as shepherds. In fact they are full-time herders, with some 
families taking care of hundreds of animals and making dozens of kilograms of cheese when milk is plentiful in the summer. Herding thus defines much of their calendars, routines, and circulations through space, within the framework of a rotational system of residence, where some areas are occupied in the wet season and others in the dry season (see Lema 2014). The consumption of animal meat occurs daily as an essential part of meals, and the slaughter of animals is common to all families.

The butchering process starts with shepherds choosing an animal (a goat or sheep). They take it out of the corral, lay it on its left side, and then quickly cut the throat, pasando el cuchillo (passing the knife), while holding the head facing east toward the morning sun to ensure future reproduction. When the head is partially separated from the body, the ánimu (main spirit of animals and people) also separates and heads eastward. This process must happen quickly to avoid suffering; otherwise, the ánimu could take revenge. It could be said that shepherds must fabricate a proper exit and show the way to the ánimu, so that it leaves and does not come back. The procedure of disgorging and handling the blood is called hacer carne (making meat), because this is when the flesh itself comes into existence. The shepherds repeatedly explained to me that although they choose a large and fat animal, the body can reveal itself as thin and empty inside if they do not perform a proper killing. Therefore, to kill an animal supposes an uncertainty that is resolved when the body is opened and herders verify whether "the meat was made."

This process also allows evaluations of the health of the slaughtered animal and of the past and future of herd reproduction. During the breeding of animals, shepherds seek to form a unit inside the corral: a group of well-behaved animals, usually called hacienda or simply corral. However, this unit is always fragile because the animals could become chúcaros (wild). The relationships with (and within) the hacienda depend on the shepherd's efforts to continuously reach an equilibrium-a constant flux of reproduction and the birth of animals, their feeding and growth, and their 'proper deaths'. A group of healthy and fat animals is the visible expression of good herding relations, past and present, and fosters fertile relations that reflect a favorable future for the corral. These resemblances between things or relations are called señas and are found throughout most of the Andes. The best known may be those described in the literature as omens: small events or facts (the song of a bird, the fat of a sheep) announcing something (a weather change, a fertile future) that must be decoded so that one can act accordingly (Kessel and Enríquez Salas 2002). However, I prefer to describe the señas in a slightly more general way-as effects of a process of co-indexing between forces and forms that partially reflect each other and in which it is possible to intervene. Thus, señas are connected with the past and future of the relationships at stake, such as fertility (see also Kohn 2013: 32-33). 
I will return now to the butchering sequence. After 'making meat' comes the skinning of the body, involving the opening of the thorax, separation of the legs, evisceration, emptying of the stomach and intestines, and cleaning off the remaining blood. These treatments reveal a very specific topology: to separate things that were together, to join others that were separate, to open, to wrap, to turn, to bend, to unfold. Shepherds emphasize that these processes and treatments must be conducted in the proper way (doblar bien, envolver bien, voltear bien). A textile vocabulary better describes these operations and the ontological status of these manipulated parts, because skin and meats are las ropitas de los animales (the little clothes of animals). Skinning is associated with an evaluation that is especially concerned with a specific relational force that is still present in fresh and wet meat and bones: suerte (luck).

In the Southern Andes, suerte is a widespread concept that broadly points to the possibility of carrying out successful activities (Arnold and Yapita 2001; Bugallo 2014; Bugallo and Vilca 2011). People can occasionally be lucky in business, agriculture, or mining, among other pursuits. Luck is not necessarily unlimited, and it may end or be damaged, depending on the relationships established with others. It is neither an abstract concept, since it can be seen, fed, and created, nor an individual one, since it is immanent in the network of relationships of people (Arnold and Yapita 2006: 233-234). In this context, suerte is a relational force that sustains the possibility of becoming a shepherd. It is a connection between different kinds of beings that develops from the first years of life when children begin to deal with animals (Arnold and Yapita 2001: 102). All shepherds must have some suerte, but it is not an internal property. Shepherds' suerte is visible in their connections with herds: not only in the well-behaved, perfect unit of the haciendas, but also inside animals, wrapped in their bodies. Suerte has material and sensitive forms that are held together by bones, flesh, and viscera-by the guts and gallbladder especially, but also by every wet part (Pazzarelli 2017). It can be seen and touched, since organs are 'relations' (Bastien 1985), but it disappears along with the humidity that evaporates from the meat.

Among the manipulated viscera is the gut corral, the upper colon. Other intestines are separated from their adipose tissue, emptied, curled, and twisted like threads to eat. Yet the corral is the object of special attention because it is full of suerte. Extracted with care and never unfolded, its content is released by making a longitudinal knife cut that, although threatening its integrity, does not affect the disposition of the intestine, the relation between its loops, or its circumference. Thus 'whole', it is roasted and eaten by the shepherds or some other member of the house; it is not shared with guests. If this corral is mistreated, the goats' pens, made of stones and wood, would 'unfold' too, affecting the desired unity of animals. Likewise, mistreated animals will not develop viscera with suerte. Many domestic punishments and threats are imposed on those who carelessly manipulate the viscera and work against suerte. 
This special treatment points to relations where viscera and pens are linked by morphological resemblances. Observation of the corral practiced during butchering, however, suggests something even more interesting. Its form proposes an original description of how movements of entrance and exit, and the relations between inside and outside, are connected. In the gut corral, the centripetal force becomes centrifugal, and both movements, which are in the same direction, are connected in the central flexure. When shepherds affirm that the gut 'looks like a corral', " they do not refer only to the circular analogy; they also refer to these internal forms and forces. They point and follow with the finger the turns of the guts, the flexure, the entrances, and the exits. The corral 'looks like a corral' because of these turns too, which are appreciated as a redundancy of the movements and forces that live in stone pens. ${ }^{2}$ It could be said that the gut corral, wrapped inside the animal body and identified as a seña index by the shepherds, at the same time evokes and invokes the corral that is outside, both when it recalls the outer corral as a set of forces of entrance and exits, twisted and folded on itself, and when the shepherds desire it whole and united for the future, and vice versa. Both corrals are señas, 'reflections' of the other, and affect and stimulate each other, as the huacheño shepherds explain (see also Arnold et al. 1996: 392; Kohn 2013: 32-33). However, as I have suggested, this could go further. When opening an animal body, shepherds not only interpret external forces between corrals; they are also looking for themselves. They open and unfold a body and rummage through the twisted viscera to find and examine a part of the relations that constitute them as herders-the wet suerte.

\section{Twists, Folds, and Wraps}

In several regions of the Southern Andes, every being is defined by the ánimu. All humans, plants, animals, and mountains have some ánimu. Considered to be a main spirit (Allen 1982, 2015; Bastien 1985; Bugallo and Vilca 2011), it has sometimes been described as a 'shadow' that accompanies the body, a 'double that animates' (Ricard Lanata 2007; Tylor 2000). In Huachichocana, the ánimu is generally described as a part of the person, often invisible, which is inside the body; its loss is always described as an 'exit' (Bugallo and Vilca 2011; Ricard Lanata 2007). This inside-outside relation is never absolute and is best thought of as consecutive wrappings-like those of a textile-between ánimu and body, where it is hard to define what is inside of what (Pazzarelli 2017).

The connections between ánimu (and other spirits) and a textile topology have been fully investigated in the Southern Andes from different perspectives (see Arnold and Yapita 2006; Arnold et al. 1996; Bugallo 2014; Cereceda (1976) 2010; Dransart 1995; Flores Ochoa 1977). In their ethnography of the Aymara highlands, Arnold and Yapita (2001) show the multiple connections between 
wool strands and textile wrappings associated with the possibility of existence and life. The first twist begins when the threads of blood and semen cross and fold to form the fetus that will then be wrapped in a woman's womb (Bastien 1985; Platt 2002). Newborns will be progressively wrapped repeatedly by textiles, until they become fully 'bundled' human beings. These "concentric wrappings" (Arnold and Yapita 2001: 35) involved in the constitutions of persons, however, are not just like circles, one inside another (cf. Platt 1986). They are better envisioned as spirals (Dransart 1995) whose loops cannot be easily described as internal to some individual, because some loops are others' wraps (Arnold and Yapita 2006: 112). Beginning with the first turn, the spiral develops turn by turn throughout life, enabling different social relations and making a thicker thread of life thanks to 'envelopes' (such as foods, songs, and chants) provided by others (relatives). At one point, the spiral is twisted together with another (when getting married). However, none of the threads ever stops twisting. It will continue until death, when the thread is unfolded as in an animal-skinning process. This physiological bundle is not just human: animals are bundles, too, and the shepherds' care is one of their wrappings (Arnold and Yapita 2001).

In Huachichocana, the shepherds want animals with good layers of fat because that makes them strong, capable of protecting their vital forces and promoting suerte. But here I want to go a step further. On the one hand, I will highlight that folds and wrappings not only reflect each other but can also be fabricated and manipulated to connect, or disconnect, with the generative forces of fertility and suerte. On the other hand, some indeterminacy is inherent in the opening of spiral bundles (as in the opening of an animal's body), and this makes the shepherds potential prey for an external agent. To move forward on this, I will return to the topological description of butchering.

\section{To Fold and to Wrap for Others}

Once the skinning ends, it is time to dry the meat and the leather. The meat with bones (the still united set of legs, thighs, ribs, spine, and sometimes head) is called carne fresca (fresh meat). It is wet, full of luck, and carries some culinary restrictions. It usually cannot be boiled and thus must be put to dry, taking special care to hang it volteado (everted), that is, turned inside out with its interior outward, in opposition to how meats wrap the viscera when the animal is alive. Turning fresh meat inside out is important. If it were not done in the proper way, the meat would parecer viva (appear to be alive) and attract predators, who would not only steal the meat but, because it is wet, would also steal the luck. When it is dry a day later, the meat loses this status, and the culinary and topological restrictions end. The last process is that of the cueritos (little leathers or skin). They must be carefully folded upon themselves, with their 
legs and head arranged as if the animal were asleep and still alive, then left in some corner of the room. It is necessary to refold the leather como ellos son, dormiditos (as the animals are, asleep) at least for a few hours, ideally until the next day. Otherwise, the ánimu that was released but still lingers will not become calm and leave this world, with dire consequences for familial luck. It seems that the animal's ánimu must 'see' the surroundings and be sure that there is no longer a place for it in this world. The hanging flesh is dead and its 'little clothes' are folded, resembling a live and already wrapped animal, a bundle where it could no longer enter. The next day, when the ánimu has left, the leather is put to dry in the sun, turning it inside out like the meat because it is still wet and connected to suerte (but no longer with ánimu).

Skins should look like living and sleeping animals; meats put to dry should not seem alive. Both situations are connected by the problem of resemblances between things and their effects on external points of view. Resemblances have to be modulated. If the meat is not properly turned inside out, the puma could steal it because it looks like a living animal. If the leather is not properly folded and does not look like a sleeping animal, the ánimu could be annoyed and try to take revenge. The aesthetic of the treatment of meats and leathers is linked to the need for others to 'see' it in a specific way: living or dead. It is because of others' views that herders must do things appropriately. Shepherds must be persuasive since they orient others' vision and perceptions. ${ }^{3}$ Unfolded, hanging meat in a corner not only makes a relation visible: it also proposes it. The relation is virtually there, but it needs the puma's view to be completed. To wrap is only a part of the process because someone else (puma, ánimu) must 'accept' the description being proposed. The meat fold reverses the topology of the living animal and opens the possibility of the existence of meat that is not completely dead for people (because it is wet, with luck) but seems to be completely dead to the puma. The folded leather resembles a sleeping live animal for the ánimu, although for people it is already an expiring life. The topological adaptation helps to deal with a situation of indeterminacy: the animals were sacrificed, but their meats are still alive, carrying an important and shared relation that could be desired by others. Folding meat and leathers while dehydrating them is an operation of disambiguation, which at the same time enables a 'partial connection': the meat will be dead for the puma, still alive for the ánimu.

This is linked to the importance of the gaze as a relational process. In the highlands, where several kilometers can be viewed without encountering any obstacles, the relations between seeing and being seen, showing and hiding, are very important. Family homes are always under gazes that cannot be controlled-neighbors walking on top of a hill, wild animals lurking in the vicinity-and it is therefore necessary to control what is shown, what is left outside the rooms, and the meats and leathers that are manipulated. Showing too much can arouse the envy of others or certain forms of sorcery (the so-called 
evil eye). The usual recommendation in an encounter with a puma is to stop moving and stare at it so that the animal acknowledges that it is facing a fearless person. In other regions of the Andes, the gaze is also the means par excellence to distinguish the specificity of the forms and contours of beings, thus avoiding 'confusions' (Allen 2015; Cereceda 1990). In the previous examples, the life (or lack of life) of meat or leather also depends on external eyes. It could be said that it is the 'work of seeing' of pumas and ánimus that makes things appear (Strathern 2013: 78-94). And on these occasions it is necessary to handle the resemblances between things to generate 'confusions' that may be productive (Kohn 2013: 84-85, 100). In the examples discussed, meats and leathers are folded and wrapped to show something that is not there, as if a mirror were made that twists the reflection of what the bodies with the removed viscera would show. The last example that I wish to present involves resemblances fabricated by neither the shepherd nor his animals' bodies.

\section{People's Corrals}

During señaladas (marking ceremonies), ${ }^{4}$ which are held in the summer (although sometimes practiced until Easter), shepherds and their guests perform the marking of animals. These events are loaded with complex details and extend for days, but I will summarize them here, highlighting four phases that show how these rituals are linked to the strength of circular forces and forms. ${ }^{5}$ It is all about fabricating corrals, using wool or persons. For each of these phases, it is indispensable to have guests (relatives or friends who are also shepherds) working under the directive of the hosts.

The first phase is defined by the arrival of the guests early in the morning. They will be fed and quickly put to work making the wool flowers that will be sewn and tied to the ears of sheep and goats. From that moment until the end of the ritual, hosts will provide alcohol, coca, and cigars for everyone. The guests sit in a circle around a ring made of crooked colored wool threads, twisted several times. This corral de lana (wool corral) surrounds the raw materials of the assignment (needles, threads, wool) and defines the limits of the task. Nothing can fall outside the limits of the wool corral, or the person responsible will be fined and forced to drink alcohol in excess (multa). Transgressing the limits and turns of the corral affects luck.

In a second phase, hosts and guests leave the previous tasks and enter into the pen to start the work of ear marking and flower sewing. This requires much more energy, and a gendered division of labor is performed. Men seek and secure the animals in a row until they are señalados (marked) by a man responsible for ear cutting, while women sew the wool flowers in the animals' ears. The task could extend for hours or even days. The animals often try to 
free themselves; sometimes men and goats duel on the floor, trying to dominate each other. The work ends when the men can no longer secure the animals or cut their ears with precision and painlessly, due to increasing fatigue and drunkenness. During all this time, the hosts make sure that the movements between the inside and outside of the pen are controlled and ritualized. No one can go in or out without drinking some alcohol or wearing a poncho. To move without being wrapped in a poncho (or something similar) is like being pelado (naked or bald) - and nothing naked (not wrapped) can be lucky. To be pelado is to appear to others as an ambiguous seña, like choosing not to 'resemble' an ongoing ritual that is all about wrappings. Yet carefully attending to all these details ensures the host's luck.

The third phase begins with the departure of people and animals from the pen. Sheep and goats will be pursued by hosts and guests until all of them start walking, almost running, in circles, replicating the corral morphology from inside, like a big, living spiral. ${ }^{6}$ Meanwhile, people start to sing $\operatorname{coplas}^{7}$ to encourage animal movements and drink libations of alcohol and maize chicha, trying to reach the herds with some drops. After three rounds, the animals are released and then driven to the east, where there is a mojón (cairn) wrapped in colored wool, together with flowers, confetti, and alcoholic libations. Again, it is about building another corral on the cairn-this time a miniature one (Bugallo 2014: 341-342) - that evokes and invokes the forces of the corral from which the animals have just emerged. Around the mojón, people begin to sing, walking and dancing in circles. From then on, men and animals will separate: the former will remain first in the cairn and then in the house, while the latter will stay on the hill. However, the intimacy gained inside the corral seems to affect the participants (ibid.: 361). Sometimes a game is played in which some men take their hosts or visitors by surprise, knock them down on the floor, and rush to 'mark' them as they do with animals, but with paint. The 'animals' then writhe and fight hard to escape.

In the fourth phase, after singing some more coplas in the cairn, the guests are called to the house to continue singing. Once settled in a room, people will form a ronda (circle) and sing with their cajas (musical instruments made of wood and leather), while dancing non-stop in circles to their right, with slow and wobbly movements. The hosts will offer drinks, coca, and cigars throughout the night. The ronda must last at least until dawn; ideally, everyone should sing all night. In the morning, the guests will be released: they can have breakfast and leave. While drunkenness sometimes makes it difficult to finish the work inside the corral, it does allow for beautiful rondas during the fourth part of the ritual. After making wool flowers and managing the animals inside the corral, the guests are expected to sing. Mouths and throats sing without stopping throughout the night, while people dance in rondas along with the rhythm of the cajas. Singing is working: it is part of the expected task of a good 
guest. At times, drunkenness can cause the singers to slump, or it can unleash fights. None of these situations is appreciated. Sleeping is not an option either, except for older guests. In any case, well-modulated drunkenness can fabricate a highly valued aesthetic expression-that of a perfect circle round of singing, music, and dance, sustained for hours without stopping. A perfect circle round is always a good seña of future fertile relations.

When hosts invite guests to such an event and when guests talk about it, the potential joy of the ceremony is described by the possibility of singing in a ronda. Going to a marking ceremony is described as ir a cantar (going to sing). Consequently, a good ritual is defined by the quality and duration of its rondas, of those circles and spirals, as a result of the successful attentions of the hosts: food and drink in appropriate quantities, leaving potential workers-singers neither very sober nor very drunk. When a ronda de coplas is solidly constituted through strong voices and dancing bodies, that is when those relations become visible. In that moment, it is evident to everybody involved that the guests have accepted the hosts' attentions and can be described as full guests. Full guests, intoxicated in an acceptable way, are señas of well-conducted relations: the herder-hosts know how to do things properly. And the relations are there, in the ronda, for all to see.

The task of the shepherd-hosts is to balance the need to attract their animals and the possibility of losing them forever if they do not know how to take care of them. The host-shepherds are busy seducing their guests in the face of the ever-present possibility of losing them forever. The forces that raise/care for animals-guests always act against the inevitable possibility that they will become wild/drunks. In both cases, nurturing relationships (in other words, suerte) connect centripetal and centrifugal forces that act against each other. That is why the final evaluation of the ritual is so important. In a ronda de coplas, guests lend their bodies to make visible the relations of which the hosts are (or wish to be) made. The shepherd-guests act as obedient animals, helping to fabricate señas and to connect the host to the good and fertile nurturing relations that every shepherd desires. Between hosts and guests there will be no envy or competition at the marking ceremony, as there might be in other domestic situations. Everyone knows that the lead perspective of the ritual is that of the host, and nobody can challenge it. The shepherd-hosts watch their guests singing with the same attention that they observe the viscera when butchering animals, trying to recognize themselves in those señas.

\section{Fabricating Reflections}

As I have pointed out, the gut corral is a seña that informs shepherds about the general condition of a herd of animals and their present and future fertility. 
However, this is not just a morphological analogy or an omen. Instead, we could say that some señas refer to events that had already begun to happen in another place. Although they are invisible as such, they can appear and be recognized in other things such as guts. These señas do not point to possibilities but to facts with which they have some continuity. For example, the poor condition of a gut corral is a reflection of the health of animals that have already begun to fall ill; or a failed round of music is a seña of nurturing relations that are no longer working. More than analogies of static morphological relations, señas could be described as effects of the same force, enacted in two specific forms. The resemblance should be read in this sense: the shepherds' evaluations of corrals testify that everything is still in place, that they are still connected with the same forces in a healthy way, a reflection partially connected to the classic definition of señas (Arnold 1996; Kessel and Enríquez Salas 2002). However, this idea can be further developed.

The seña of the gut corral is inscribed in a different ontological plane. The inside of the animal body, where the twisted viscera are wrapped, is not part of the same world to which people and the stone pen belong-at least not completely. The difference between inside and outside, however, is not an absolute one; it depends on the thickness of the wrapping, on the quantity of loops. During my fieldwork, the shepherds subtly taught me that observing the viscera allows for a more effective observation of the health of relations, as if avoiding the mediation of so many wrappings. But at the same time, the scarcity of wrappings gives them fragility: if not treated with care, the gut corral can be easily ruined or even fall prey to others.

In the daily treatment of animals, shepherds secure these wrappings through practices that are easily recognizable: feeding, keeping away predators, curing, and singing (Arnold and Yapita 2001). These practices deal with suerte, although through the mediation of many intermediary twists and wrapping: luck in the stone pen is not visible in such clear and direct ways as in the guts. However, it is there to be seen, experienced, and manipulated. During the marking ceremonies, on the other hand, the shepherds make these breeding relations emerge using the bodies and throats of their guests to fabricate a temporary, almost ephemeral, corral. They fabricate the seña of which they wish to be a part, so as to stimulate resemblances in other dimensions of their lives. Again, we see the shepherds trying to find themselves in the bodies and affections of others, as when they stir up the viscera of their animals. We are referring to forms that, in the shepherds' eyes, allow the capture and emergence of forces that would otherwise be invisible (Viveiros de Castro 1996: 117): the corrals are similar because they both present and describe a force, twisted in a particular morphology and topology.

Hacer las cosas bien (doing things properly) - making meat, folding, wrapping, feeding, dancing - allows relations to continue to be similar, to resemble 
each other and then still connect with the same force, like a permanent and ongoing effort for the fabrication of 'sameness' (see the introduction to this issue). But these force-forms always demand to be seen in order to be completed. Herding relationships can be evaluated in viscera, and their señas can be fabricated and modulated in rondas to be seen by shepherds, family members, and guests. In these evaluations, the health of the relationships is secured when it is incorporated in the shepherd's view. It could be said that this 'work of seeing' (Strathern 2013) points to the unambiguous recognition (and sometimes fabrication) of these forces and forms (as corrales, pens, and rondas), helping these relationships to continue to be replicated everywhere, making them part of a larger generative movement.

Arnold and Yapita (2001) propose that similar arguments regarding growing connections between fertile forces are close to the 'merographic connection' described by Strathern (1992; see also Arnold 1996). The merographic connection refers to the way in which different sets of relationships are connected to others through an act of redescription and are thus included in another context, all associated with a 'procreative model', as suggested by Strathern (1992: 72-87). Strathern states that "the very act of description makes what is being described a part of something else" (ibid.: 204n21), which "rests in the (Western) apperception that persons work to bring into relationship with one another whole different orders of phenomena, as different ways of knowing the world and as different perspectives on it" (ibid.: 205n22). According to Arnold and Yapita (2001: 200-201), this is similar to some Andean ways of thinking and building relations that try to connect different domains of experience (by creating similarities between pens, one might say) in order to stimulate fertility and luck. This could also be described through reproductive, causative, or stimulus analogies-those that, given specific similarities, provoke certain reactions and seek to connect different dimensions of the world (Arnold 1996: 22; Arnold et al. 1992: 172; Arnold et al. 1996: 392, 406-410). Following this approach, all shepherds and animals grow together within the framework of mutually dependent relations (Arnold and Yapita 2001; see also the introduction to this issue). I think this connection between merographic and Andean thinking could be useful in some contexts, as in the ronda de coplas, where the guests lend their bodies and voices to join the perspective of the shepherd-host, which prevails over all others. However, the ethnography of butchering is slightly different and does not resemble a merographic connection.

It is important to bear in mind that the animal body is the result of an intense process of mutual constitution with the shepherd. As a result, the butchering process illustrates that, inside animals, shepherds find organs that are, in fact, relations (Bastien 1985). It could be argued that these organs are never objects; they are always parts of other subjects (Strathern 1992). ${ }^{8}$ This situation has strong resemblances with the Mesoamerican thought about folds 
and wrappings analyzed by Pitarch (2013), where the beings constitute an open set of wrapped perspectives. Persons (and other beings) are bundles composed of other parts of persons (and other beings). Pitarch's work proposes a Mesoamerican rereading of Amazonian perspectivism since these folds and wrappings act as perspectives that are not always compatible with each other and must be correctly handled to avoid falling prey to strange beings (ibid.: 118-119; cf. Lima 2002; Viveiros de Castro 1996). This may represent a case of topological perspectivism: the connections between different beings and perspectives depend on the correct execution of the operations of wrapping and unwrapping. By alternately showing and hiding, these operations orient the development of alien gazes. ${ }^{9}$

Similarly, in Huachichocana the topological operations at times have to deal with the gazes of other beings, and the worlds enacted by these relations cannot be easily incorporated in other perspectives without danger. The folding and wrapping of meat and leather take care of modulating the connections with other beings, assuming the ambiguous position that the moist parts of animals possess. To topologically manage this ambiguity is to assume that animal sacrifice and butchering connect different sides of the world, different beings (since part of the shepherd is retained in the moist animal meat), and that this connection will persist until the dehydration process ends. This is when pumas and ánimus could dangerously pounce into shepherds' relations. The human relational world is always being challenged by external points of view and can sometimes be seduced into seeing some things and not others-an 'art of seduction' as an aesthetic modulation of perspectives (Lagrou 2007: 137-155). In these situations, the topological adjustments try to modulate and lead the puma and the ánimu's gaze so that it develops in a direction that does not affect the shepherd's world of relations. The process of wrapping and everting meats and leathers introduces a difference and prevents a connection. As Strathern (1999: 247-249) argues, in the merographic connection "each perspective in including another viewpoint as a part of itself must exclude the other as a perspective," while "[in perspectivism] the point at which the viewer was conscious that he or she had a perspective on things would be the point at which he or she would meet (so to speak) the reciprocal perspectives of other life forms. Each would thus include the other's perspective as a perspective."

This point of view could be useful in thinking about those fabricated señas in Huachichocana that attempt to keep worlds apart. After exploring analogical and merographic thought in the Andes, a more recent book by Arnold and Yapita (2006: 272-274) poses some similar arguments about the constitution of the self in relation to the other. They argue that in certain situations the logics of ontological predation are expressed in a similar way to how they are defined for lowland perspectivism-as a vital process of incorporation of the other (as a subject) into the self (Viveiros de Castro 1996). In some contexts, suerte 
would also be the result of a similar process: “'Luck' designates an aspect of the fertilizing forces incarnate in the captured enemy that has to be released. In releasing this 'luck', the captured thoughts in the head of the other are thereby transformed for one's own benefit" (Arnold and Yapita 2006: 233; see also 274). This Andean modulation of perspectivism (Allen 2015), as well as the Mesoamerican one (Pitarch 2013), has descriptive potential to further utilize our ethnographic data. Arnold and Yapita's (2006) interpretation of suerte rests on descriptions of warlike situations involving the capture of enemies and is more or less literal, depending on the case. In our example, the relation is between non-coincident human and non-human perspectives that challenge one another and can occasionally be described as enmity, especially between pumas and shepherds fighting for sheep and goats.

The question that emerges, then, is, why would a folded meat that 'looks dead' not be interesting from the puma's perspective? In this sense, a folded 'dead' meat is pure object, and because of this the puma will not want to wrap itself with it (as in a merographic connection when things-as objects are incorporated into one's perspective). Instead, as the shepherds with whom I worked maintain, the puma is interested in the 'lucky' meat, the 'still alive' meat, with a 'shepherd' inside. The puma wants that meat because of its perspectival quality and not despite it (see Strathern 2013: 388-391). Using the forces of topological relations to seduce others' vision, as in the case developed by Pitarch, the huacheño shepherds disguise and hide their suerte retained by the moist meat. We are in the presence of almost simultaneous relations that express the existence of two non-coincident perspectives about the same thing (see also Arnold and Yapita 2006: 100). This is perhaps what the shepherds tried to teach me: when the puma looks at the hanging meat, it does not see what we see. It sees what the shepherd sees as only a part of reality, but upon seeing it, that 'part' becomes a 'whole' for the puma (Lima 2002). Only in this way does the puma move away from the houses disregarding the 'dead' meat. Here, the reflection capacity of señas is twisted to reflect just a part of the animal-shepherd bundle, like a skewed mirror. And that could approximate a perspective definition of seña.

\section{Closing Remarks}

In this text I have attempted to describe and analyze the forces that in the Southern Andes exist in connection with others-forces that reflect each other mutually yet never identically. They are redundant relations of similarity (Platt 1986), vital for life and fertility, which nonetheless always emerge in specific forms, differentiating each being or set of relations. I have developed this analysis through the idea of seña, understood as a resemblance or co-indexing process between 
beings or parts of beings, and through specific examples involving the corral and its capability to promote suerte. Corral and suerte are presented as coincident forces/forms that are potentially present in viscera, material structures, objects (wool), body movements, and dances. In line with the introduction to this special issue, these resemblances point toward an idea of mutual dependence between beings (Arnold and Yapita 2001; Bugallo 2014; Lema 2014). Each being or context connects with the same corral (the same topological force of the circle and the spiral) and the same luck, although corral and luck are always expressed as something different for each of them. Similar arguments are found in other regions of the Andes (Allen 2015; Arnold 1996; Arnold et al. 1992; Franquemont et al. 1992). From these points of view, connecting different dimensions of life would imply incorporating corral and suerte into a larger generative movement, activating stimulus analogies or merographic connections in their Andean modulation.

But the ontological status of the topological relations in Huachichocana supposes other interesting movements, because relations can sometimes be evaluated, manipulated, and fabricated to avoid connections rather than activate them. Resemblances are not always encouraged; not all topological operations seek unambiguous relationships, nor do they attempt to intensify connections between forces and forms. All this is made explicit in the butchering process. When shepherds kill and open an animal, they find not just the traces of an external 'individual' or object capable of being incorporated as part of other things (as in a merographic connection). They also find a trace of a person, a trace of themselves wrapped in their animals that could be potential prey for others. When folding meats and leathers, shepherds try to prevent their world from resembling the world of the pumas by making it unattractive to them. These operations that disguise the subjects wrapped in animal bodies are intended to keep things separate, to reinforce difference. The analysis in this article advances these concepts, proposing some ideas to think about relationships as forces/forms that can (and sometimes must) be twisted.

I have argued that the perspectival quality of these Andean relations resembles both the Amazonian (Allen 2015; Arnold and Yapita 2001, 2006) and the Mesoamerican (Pitarch 2013) models. But before attempting to find perspectivism in the Andes, we can use the descriptive and analytical potential of these concepts to better describe our contexts (as also pointed out by Allen 2015). Resorting to the discussion on perspectivism allows us to emphasize that not all topological relations, or señas, linked to suerte can be described as analogical. Analogies and merographic connections are only a part of the story. To fully comprehend the shepherds' world of relations, it is necessary to introduce the topological Andean version of the difference of perspectives. In the examples provided in this article, these differences are expressed in terms of predatory relations (ánimu-shepherd, puma-shepherd). In the literature, these 
dangerous or destructive relations have often been treated as counterparts of fertility, as if, in a process of taming, the shepherds incorporate danger or destruction in their lives as fuel to boost fertility. But in this dual balance, the weight of fertility is always greater.

This type of merographic connection, which subsumes danger (as an object) under fertility, can be useful to analyze some cases, as in the rounds of coplas, when current enmities between shepherds are suspended to join the perspective of the host. But other contexts simply do not operate like that. When shepherds fold leathers and meats, they look for a different type of connection; they are attentive to the gaze of the pumas, who seem to have little interest in fertility. It is not a perspective added to another here. It is two points of view that cannot be simultaneous: one challenges the other. Shepherds defend themselves by twisting relations, folding meats and leathers so that the world 'looks like' something else.

At this point, the ethnography of Huachichocana can perhaps provide elements to think about an Amerindian theory of relations that needs no totalizing models. Drawing comparisons with the lowlands and Mesoamerica (even with Melanesia) can be helpful to explore continuities between ways of fabricating relations that overcome the so-called ontological barriers. The viscera of the huacheños may be useful to illustrate that many almost simultaneous worlds exist between fertility and predation.

\section{Acknowledgments}

I am very grateful to Giovanna Bacchiddu, Florencia Tola, Piero Di Giminiani, and Marcelo González Galvez for organizing the fascinating workshop "What Is a Relation?” Special thanks go to Els Lagrou, Marcelo González Galvez, and José Antonio Kelly for their challenging comments. Luisa Elvira Belaúnde, Denise Arnold, Verónica Lema, José María Miranda, and Indira Caballero also provided illuminating readings. Finally, I am grateful to the anonymous readers and to Martin Holbraad, the editor of Social Analysis, for their inspiring comments. This article draws on the project "Cosmopolitics of Cooking," financed by the Faculty of Philosophy and Humanities, National University of Córdoba, Argentina, from 2016-2018. 
Francisco Pazzarelli is an Assistant Professor in the Department of Anthropology at the National University of Córdoba, Argentina, and is an Adjunct Researcher in the National Council of Scientific and Technical Investigations (CONICET). Over the last decade he has conducted extensive archaeological and ethnographic fieldwork in northern Argentina in the provinces of Catamarca and Jujuy (in the Southern Andes). His research focuses on issues of culinary practices, material culture studies, and human-animal relationships. Recent articles include "A sorte da carne: Topologia animal nos Andes meridionais" (Horizontes Antropológicos, 2017) and "Paisajes, vidas y equivocaciones en los Andes meridionales (Jujuy, Argentina)” (Chungará, 2018). E-mail: fpazzarelli@hotmail.com

\section{Notes}

1. Harris (1986: 279n16) suggests that the notion about circular forms could even precede that about squares and corners characteristic of the Inca period.

2. On the generative force of forms, see Arnold and Yapita (2001) and Franquemont et al. (1992).

3. I use the verb 'orient' in connection with Strathern's (1992: 57) commentary on Munn's work in Melanesia: “The very process of making something visible is a social act that orients the entity (person, vessel) outwards towards those in whose eyes it appears."

4. The word señalada derives from the Spanish words señal and señales, in reference to the ceremonial cuts made in the ears of animals; but it has no relation, far as I know, to the word seña.

5. Full descriptions of similar events can be found in Arnold and Yapita (2001), Bugallo (2014), and Dransart (1991).

6. Dransart (1995: 236) makes a similar observation about the Isluga community in northern Chile: "The dance movements inside the corral, during the earlier part of the ceremony, more closely reflect the stages involved in spinning and plying yarn."

7. The copla, a poetic musical genre of mixed origin (pre-Hispanic and Spanish), generally employs four thematically linked verses.

8. Drawing on Wagner (1977), Strathern (1992: 79) explains this in more detail: "When a Melanesian looks inside a person (a relation), he or she finds other persons (relations). But such a relative is thereby composed of other relatives only insofar as the person takes on the task of attending to them. A flow of substance may be perceived as a reason for a counter-flow of gifts, thus producing a social relationship that contains the flow ... The Melanesian person thereby sustains the image of flowing substance through the wealth that is returned in the opposite direction, even as his or her descendants may return the flow (the substance) to him or her." 
9. References to 'topological' mirrors and reflections are also present in Mesoamerica. As Pitarch (2013: 24) puts it: "The mirror does not reflect: it unwraps, it unfolds."

\section{References}

Allen, Catherine. 1982. "Body and Soul in Quechua Thought.” Journal of Latin American Lore 8 (2): 179-196.

Allen, Catherine. 2015. "The Whole World Is Watching: New Perspectives on Andean Animism." In The Archaeology of Wak'as: Explorations of the Sacred in the Pre-Columbian Andes, ed. Tamara L. Bray, 23-46. Boulder: University Press of Colorado.

Arnold, Denise Y. 1996. “Introducción.” In Arnold and Yapita 1996, 1-28.

Arnold, Denise Y., Domingo Jiménez, and Juan de Dios Yapita, eds. 1992. Hacia un orden andino de las cosas: Tres pistas de los Andes meridionales [Toward an Andean order of things: Three tracks of the Southern Andes]. La Paz: ILCA.

Arnold, Denise Y., and Juan de Dios Yapita, eds. 1996. Madre melliza y sus crías: Ispall mama wawampi, antología de la papa [Twin Mother and her babies: Ispall Mama Wawampi, anthology of the potato]. La Paz: Hisbol and ILCA. Arnold, Denise Y., and Juan de Dios Yapita. 2001. River of Fleece, River of Song: Singing to the Animals, an Andean Poetics of Creation. Bonn: BAS and ILCA.

Arnold, Denise Y., and Juan de Dios Yapita. 2006. The Metamorphosis of Heads: Textual Struggles, Education, and Land in the Andes. Pittsburgh, PA: University of Pittsburgh Press.

Arnold, Denise Y., Juan de Dios Yapita, and Cipriana Apaza M. 1996. “Qipa Mama wawampi: Analogías de la producción de la papa en los textiles de Chukiñapi, Bolivia” [Qipa Mama wawampi: Analogies of potato production in the textiles of Chukiñapi, Bolivia]. In Arnold and Yapita 1996, 373-411.

Bastien, Joseph W. (1978) 1996. La montaña del cóndor: Metáfora y ritual en un ayllu andino [The mountain of the condor: Metaphor and ritual in an Andean ayllu]. La Paz: Hisbol.

Bastien, Joseph W. 1985. “Qollahuaya-Andean Body Concepts: A TopographicalHydraulic Model of Physiology.” American Anthropologist (n.s.) 87 (3): 595-611. Bugallo, Lucila. 2014. "Flores para el ganado: Una concepción puneña del multiplico (puna de Jujuy, Argentina)” [Flowers for cattle: A puneña conception of multiplico (puna de Jujuy, Argentina)]. In Comprender los rituales ganaderos en los Andes y más allá: Etnografía de lidias, herranzas y arrierías [Understanding livestock rituals in the Andes and beyond: Ethnography of wrestlers, herrenzas, and arrierías] ed. Juan Javier Rivera Andía, 311-363. Aachen: Shaker Verglag.

Bugallo, Lucila, and Mario Vilca. 2011. "Cuidando el ánimu: Salud y enfermedad en el mundo andino (puna y quebrada de Jujuy, Argentina)" [Caring for the animus: Health and disease in the Andean world (puna and quebrada de Jujuy, Argentina)]. Nuevo Mundo. http://nuevomundo.revues.org/61781. 
Cereceda, Verónica. (1976) 2010. "Semiología de los textiles andinos: Las talegas de Isluga” [Semiology of Andean textiles: The talegas of Isluga]. Chungará 42 (1): 181-198.

Cereceda, Verónica. 1990. "A partir de los colores de un pájaro” [From the colors of a bird]. Boletín del Museo Chileno de Arte Precolombino 4: 57-104.

Dransart, Penny. 1991. "Fibre to Fabric: The Role of Fibre in Camelid Economies in Prehispanic and Contemporary Chile.” PhD diss., University of Oxford.

Dransart, Penny. 1995. "Inner Worlds and the Event of a Thread in Isluga, Northern Chile." In Andean Art: Visual Expression and Its Relation to Andean Beliefs and Values, ed. Penny Dransart, 228-242. Aldershot: Avebury.

Flores Ochoa, Jorge. 1977. "Aspectos mágicos del pastoreo: Enqa, enqychu, illa y khuya rumi” [Magical aspects of grazing: Enqa, enqychu, illa, and khuya rumi]. In Pastores de puna: Uywamichiq punarunakuna [Pastors of puna: Uywamichiq punarunakuna], ed. Jorge Flores Ochoa, 211-237. Lima: Instituto de Estudios Peruanos.

Franquemont, Edward M., Christine Franquemont, and Billie Jean Isbell. 1992. "Awaq ñawin: El ojo del tejedor, la práctica de la cultura en el tejido" [Awaq ñawin: Weaver's eye, the practice of fabric culture]. Revista Andina 10 (1): 47-80.

Harris, Olivia. 1986. "From Asymmetry to Triangle: Symbolic Transformations in Northern Potosi." In Murra et al. 1986, 260-279.

Kessel, Juan van, and Porfirio Enríquez Salas. 2002. Señas y señaleros de la Santa Tierra: Agronomía andina [Signs and signalers of the Holy Land: Andean Agronomy]. Quito: Abya Yala/IECTA.

Kohn, Eduardo. 2013. How Forests Think: Toward an Anthropology Beyond the Human. Berkeley: University of California Press.

Lagrou, Els. 2007. A fluidez da forma: Arte, alteridade e agência em uma sociedade amazônica (Kaxinawa, Acre) [The fluidity of form: Art, alterity, and agency in an Amazonian society (Kaxinawa, Acre)]. Rio de Janeiro: TopBooks.

Lema, Verónica. 2014. “Criar y ser criados por las plantas y sus espacios en los Andes septentrionales de Argentina” [Raise and being raised by plants and their spaces in the northern Andes of Argentina]. In Espacialidades Altoandinas [High Andean spaces], ed. Alejandro Benedetti and Jorge Tomasi, 301-338. Buenos Aires: FFyL-UBA.

Lévi-Strauss, Claude. 1966. Mythologiques. Vol. 2: Du miel auz cendres [From honey to ashes]. Paris: Plon.

Lima, Tânia S. 2002. "O que é um corpo?” [What is a body?]. Religião \& Sociedade 22 (1): 9-20.

Murra, John V., Nathan Wachtel, and Jacques Revel, eds. 1986. Anthropological History of Andean Polities. Cambridge: Cambridge University Press. Originally published in French in 1978.

Pazzarelli, Francisco. 2017. "A sorte da carne: Topologia animal nos Andes meridionais" [The luck of the flesh: Animal topology in the southern Andes]. Horizontes Antropológicos 23 (48): 129-149. 
Pitarch, Pedro. 2013. La cara oculta del pliegue: Antropología indígena [The hidden side of the fold: Indigenous anthropology]. Mexico City: Artes de México.

Platt, Tristan. 1986. "Mirrors and Maize: The Concept of Yanantin among the Macha of Bolivia.” In Murra et al. 1986, 228-259.

Platt, Tristan. 2002. "El feto agresivo: Parto, formación de la persona y mito-historia en los Andes" [The aggressive fetus: Childbirth, formation of the person, and myth-history in the Andes]. Estudios Atacameños 22: 127-155.

Ricard Lanata, Xavier. 2007. Ladrones de sombra: El universo religioso de los pastores del Ausangate (Andes surperuanos) [The thieves of shadows: The religious universe of the shepherds of the Ausangate (South Peruvian Andes)]. Lima: Instituto Francés de Estudios Andinos/Centro Bartolomé de las Casas.

Strathern, Marilyn. 1992. After Nature: English Kinship in the Late Twentieth Century. Cambridge: Cambridge University Press.

Strathern, Marilyn. 1999. “The Ethnographic Effect II.” In Property, Substance and Effect: Anthropological Essays on Persons and Things, ed. Marilyn Strathern, 229-261. London: Athlone Press.

Strathern, Marilyn. 2013. Learning to See in Melanesia: Four Lectures Given in the Department of Social Anthropology, Cambridge University, 1993-2008. London: HAU Books.

Tylor, Gérald. 2000. Camac, camay y camasca y otros ensayos sobre Huarochirí $y$ Yauyos [Camac, camay and camasca and other essays on Huarochirí and Yauyos]. Cuzco: IFEA-CBC.

Viveiros de Castro, Eduardo. 1996. “Os pronomes cosmológicos e o perspectivismo ameríndio" [The cosmological pronouns and Amerindian perspectivism]. Mana 2 (2): 115-144.

Viveiros de Castro, Eduardo. 2002. A inconstância da alma selvagem e outros ensaios de antropologia [The inconstancy of the savage soul and other anthropological essays]. São Paulo: Cosac Naify.

Wagner, Roy. 1977. “Analogic Kinship: A Daribi Example.” American Ethnologist 4 (4): 623-642. 